\title{
A SPECIES OF EPISTENIA (HYMENOPTERA, CHALCIDOIDEA) FROM COLORADO
}

\author{
BY T. D. A. COCKERELL \\ University of Colorado, Boulder, Colo.
}

On April 5, 1934, Mr. Charles H. Hicks bred a very beautiful Chalcidoid from the nest of an Odynerid wasp, found a short distance above the mouth of Boulder Canyon, Boulder County, Colorado. Trying to determine its affinities, I thought it might be referable to the genus Ormyrodes of Brues, said to be recognisable by "the extremely long, awlshaped abdomen, uniformly punctuate body, hairy eyes, and long postmarginal vein in wings." The hind coxæ, also are considerably enlarged. However, there were discordant characters: the shorter abdomen, not at all constricted at end of third segment, and first tergite smooth, as well as the well developed parapsidal grooves. The specimen was transmitted to the Museum of Comparative Zoology, and Professor C. T. Brues kindly examined it and at once referred it to the genus Epistenia of Westwood, of the Cleonymidæ. This is a widespread genus of rather numerous species, but apparently they are nowhere common, as I do not remember ever having captured a specimen. The resemblance to the Ormyridæ is presumably entirely superficial. Up to the present time 24 species of Epistenia have been described, distributed as follows: Georgia (1), California (1), Guatemala (1), Panama (2), Brazil (5), Paraguay (4), Peru (1), Chile (2), South Africa (1), Philippines (1), Borneo (2), Queensland (3). The Colorado species has the following characters:

\section{Epistenia regalis sp. n.}

Female: Length about $8 \mathrm{~mm}$.; anterior wing nearly 5; elongate, coarsely punctured, head, thorax, abdomen and coxæ rich purple, legs otherwise clear red, with very fine pruinose white pubescence; antennæ long, with a stout black 
flagellum, pointed at apex, its basal joint blue; the long scape, shining greenish blue on outer side, is inserted very little above the mouth; head and thorax dull, with very dense coarse punctures, making a cancellate surface; profile of thorax above practically straight; prothorax very large, swollen, parapsidal grooves very distinct, the mesonotum accordingly trilobed; a black curved keel bounding axillary region anteriorly; scutellum very large and convex, with no groove, the apex nipple-like; base of metathorax shining; tegulæ small and black; wings hyaline with black veins; marginal vein less than half length of submarginal; stigmal long and distinct, thickened at end; postmarginal at least as long as marginal; front femora robust, with a tooth beneath toward end; hind femora moderately stout; the large hind coxæ rough with fine dense punctures, running in rows; abdomen nearly $5 \mathrm{~mm}$. long, long-fusiform; the short first tergite smooth, shining green and rosy; second to fourth deep purple, with black hind margins, the surface covered with very large round punctures, not in rows, the dorsum not keeled; apical part of abdomen black and keeled, the ovipositor little exserted. The eyes have very long hairs.

Type in Museum of Comparative Zoology, Cambridge, Mass.

It may be that all the species of Epistenia are parasitic on Eumenidæ. E. odyneri Ashmead (Psyche, VII, 1896, p. 336) was bred by Dr. A. Davidson in California from Odynerus rufobasilaris Ashmead. It is quite a different species, the female $6 \mathrm{~mm}$. long, strongly green, flagellum rufopiceous beneath, knees honey-yellow, tibiæ and tarsi dark fuscous. 

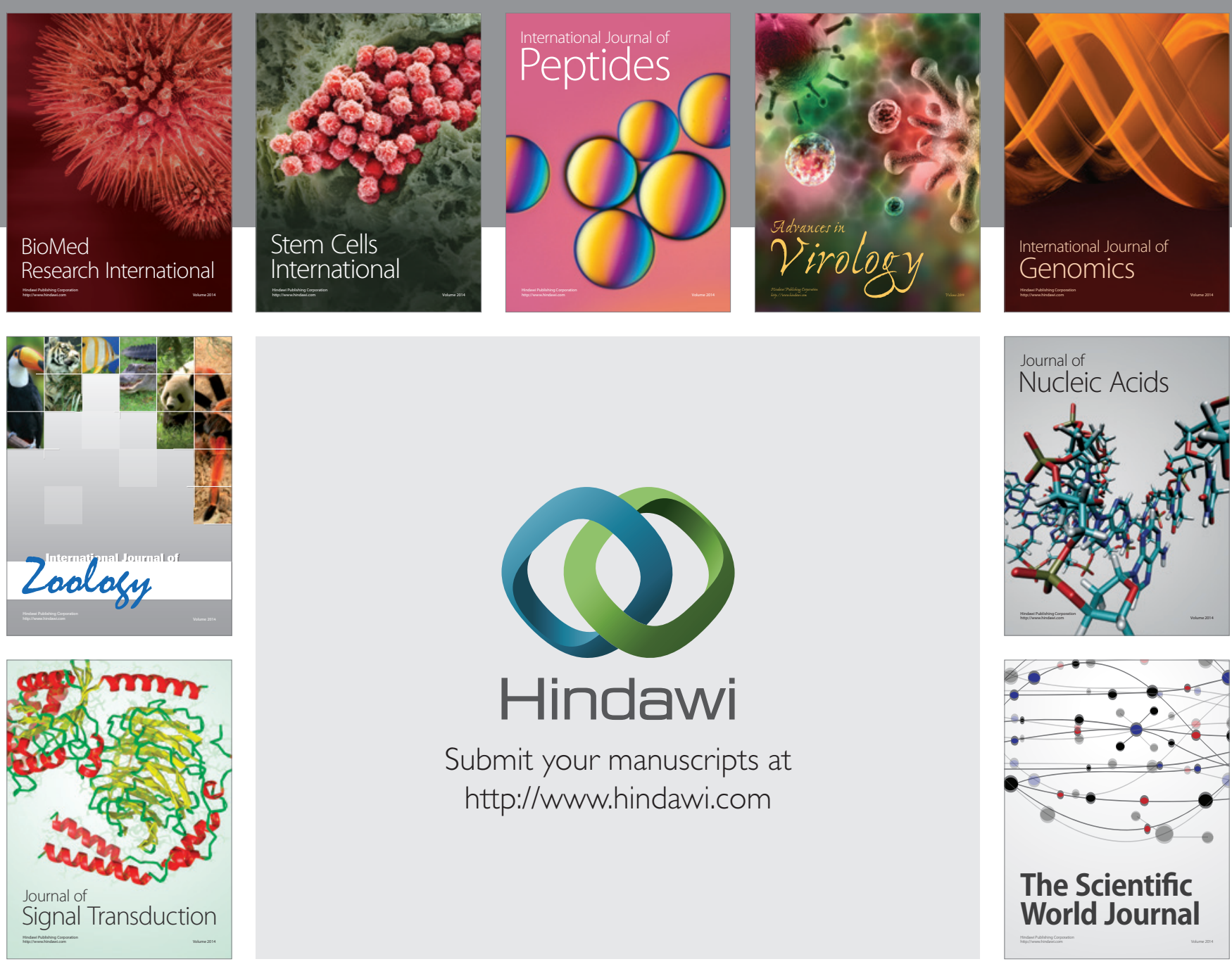

Submit your manuscripts at

http://www.hindawi.com
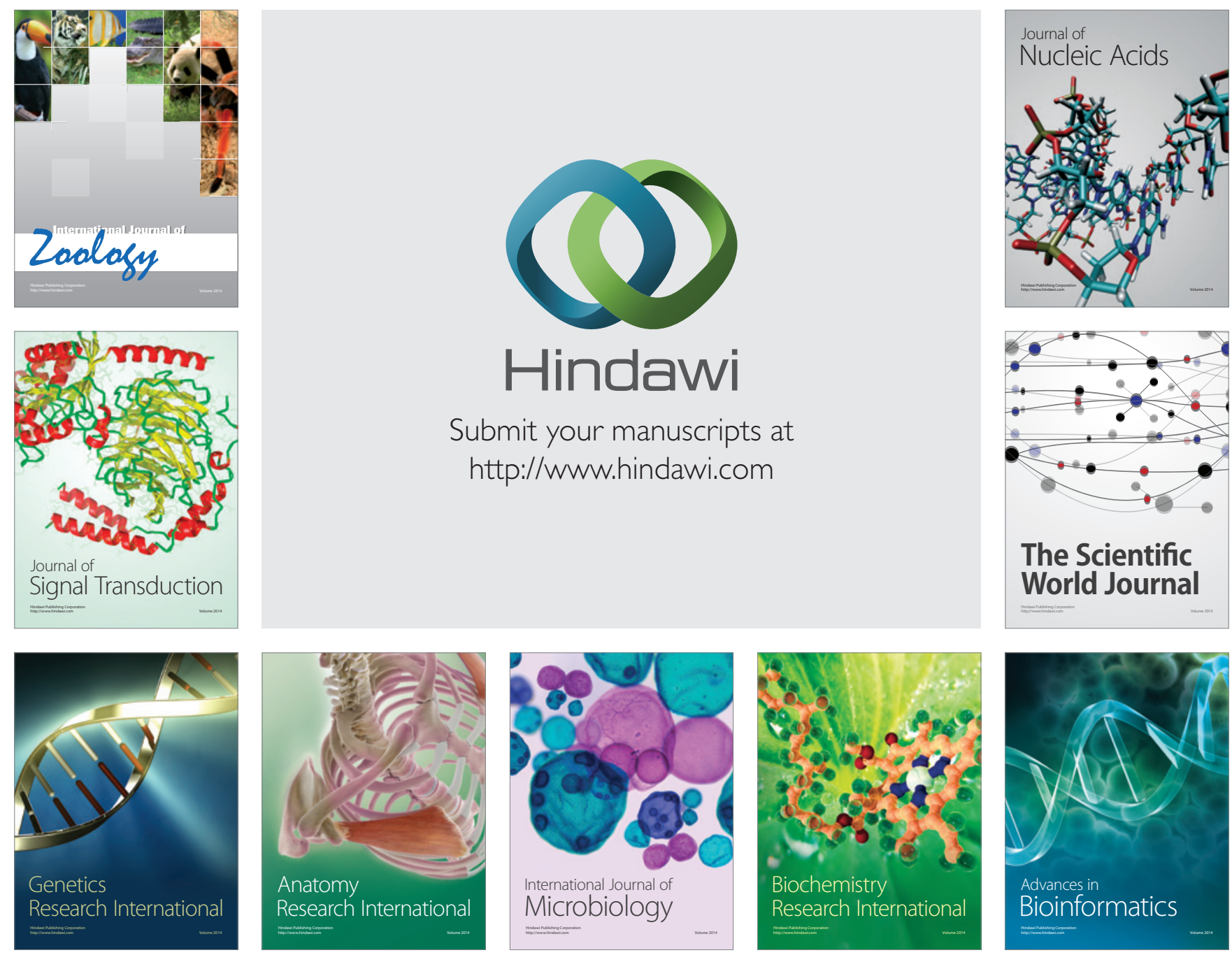

The Scientific World Journal
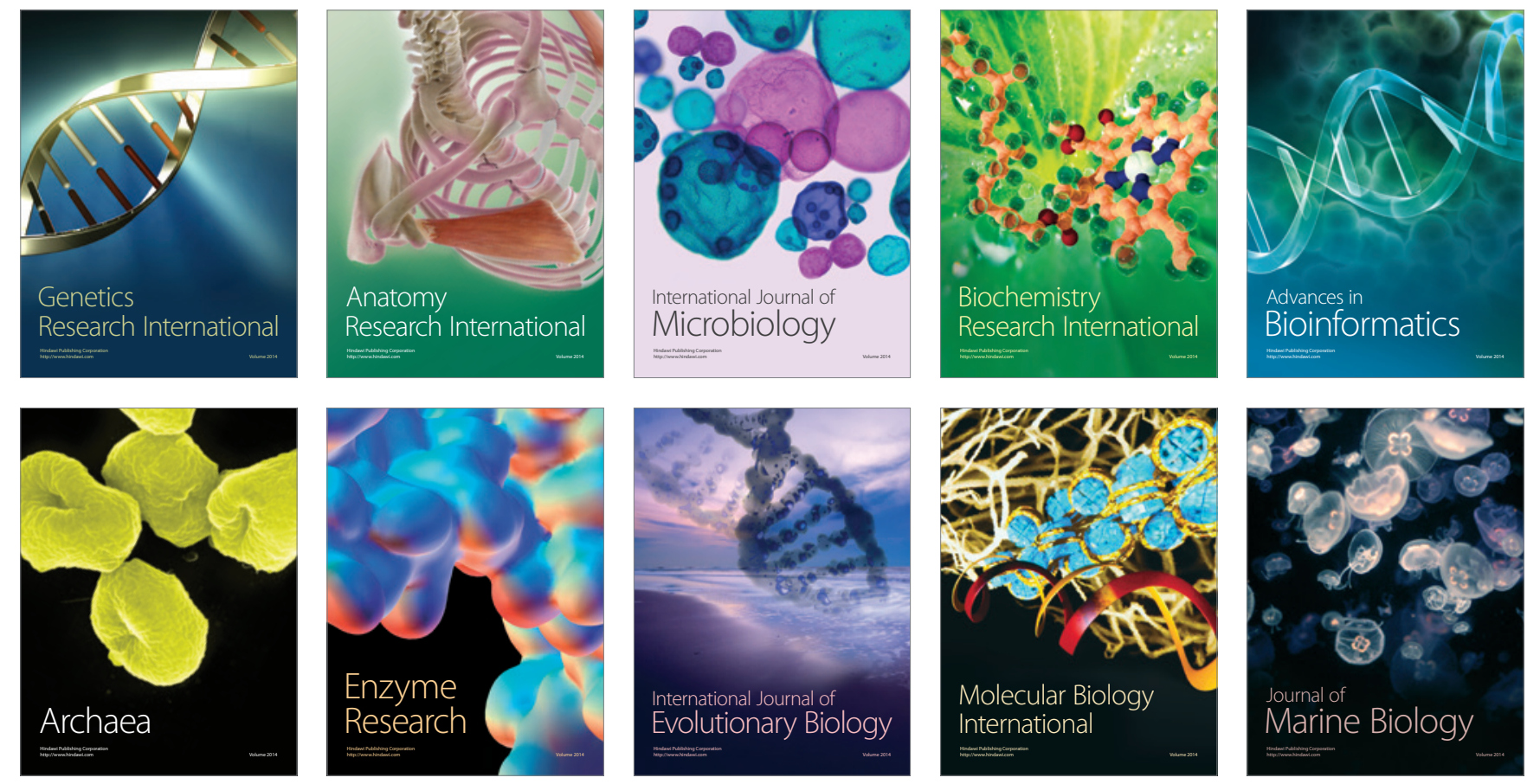